\title{
PAID MATERNITY LEAVE AND CHILD MORTALITY IN ASIA AND THE PACIFIC
}

\author{
Grace Puliyel, Hoolda Kim and Sophie Mitra*
}

Despite gains in reducing the mortality rates of infants and children in Asia and the Pacific, millions continue to die each year from preventable causes. A growing body of research highlights that more generous maternity leave has significant development benefits, especially with regard to infant mortality and child health outcomes. Little is known, however, about the impact of national maternity leave policies specifically in Asia and the Pacific.

The objective of the present paper is to evaluate whether paid maternity leave affects infant and child mortality in 34 countries of Asia and the Pacific between 1991 and 2016, using a fixed effects model. The results indicate that national guarantees of paid maternity leave are associated with lower infant mortality overall and lower under-five mortality, in particular among the upper-middle income countries. These results are consistent with research indicating that paid maternity leave is likely to allow new mothers time to breastfeed, care for ill babies and ensure that their children receive vaccinations.

Efforts to expand paid maternity leave across the region could make a substantial difference in parents' ability to care for their children and also facilitate the emotional and physical recovery of mothers, contribute towards increased income security, promote employment continuity and advance gender equality. In line with international standards, the duration of leave, wage replacement rate and extent of coverage should be carefully considered to ensure the full effectiveness of maternity leave policies. Furthermore, in the context of a burgeoning informal economy in which women are distinctly overrepresented, it is hoped that the findings of this paper will influence Asian and Pacific Governments to learn from the experience of other countries in ensuring legal provision of paid maternity leave and also extending muchneeded maternity protection coverage to women workers beyond the formal sector.

JEL classification: J13, J16, I12, I18

Keywords: childcare, maternity, mortality rates, entitlements

Grace Puliyel, former staff member of the Social Development Division of the Economic and Social Commission for Asia and the Pacific (ESCAP) (email: puliyel@un.org). Hoolda Kim, Assistant Professor of Economics, Black Hills State University, South Dakota, United States. Sophie Mitra, Professor of Economics, Fordham University, New York, United States. The authors would like to specially thank Fordham University for hosting a research visit from May to August 2018, and acknowledge support received from the United Nations Sabbatical Programme, in enabling the development of the present paper. The paper is dedicated to the memory of Mammen Puliyel. 


\section{INTRODUCTION}

Maternity protection is a fundamental human right enshrined in the Universal Declaration of Human Rights, ${ }^{1}$ among other key frameworks, and is an indispensable element of comprehensive work-family policies (ILO, 2014). The duration of maternity leave and the level of income replacement, in addition to the observance of the provisions in practice, are central factors in assessing maternity protection legislation and its association with women's health, their status in the workforce and gender equality at work, in general.

Research indicates that there are clear costs associated with very short leave provision and a low level of income replacement, as mothers may not be ready to return to work and are thus associated with a high risk of dropping out of the labour market altogether (Keck and Saraceno, 2013). It also has a considerable effect on facilitating emotional and physical recovery, ensuring employment continuity and, by sustaining a mother's economic independence, it can act to challenge the traditional gender division of labour in the household (Grimshaw and Rubery, 2015).

In Asia-Pacific countries, the provision of maternity leave is generally available to workers in the formal sector. The average duration of maternity leave in the region had been gradually increasing (figure 1). It must be noted, however, that some countries have not changed the length of their maternity leave allowances in this period, such as Indonesia and Japan, and that one country, Papua New Guinea, grants unpaid maternity leave.

Of the 46 economies $^{2}$ in Asia and the Pacific with available data, 40 of them ${ }^{3}$ mandate maternity leave, 24 mandate paternity leave and just 13 mandate parental leave. In addition, public childcare services are provided by just 25 economies, while parents receive allowances for children under six years old in only 17 countries. ${ }^{4}$

The International Labour Organization stipulates that mothers should be entitled to a minimum paid maternity leave of 14 weeks (Convention No. 183) ${ }^{5}$ and encourages

\section{Resolution 217 A (III).}

2 Data are not available for the following economies: Democratic People's Republic of Korea; Turkmenistan; Tuvalu; American Samoa; Cook Islands, French Polynesia; Guam; Macao, China; Nauru; New Caledonia; Niue; and Northern Mariana Islands.

3 The following economies do not legally mandate unpaid or paid maternity leave: Marshall Islands, Micronesia (Federated States of), Palau and Tonga. Notably, Australia and New Zealand mandate parental leave, which can be shared between the mother and father as they choose.

4 World Bank's Women, Business and the Law 2018 database.

5 C183 - Maternity Protection Convention, 2000 (No. 183), 88th ILC session, 15 June 2000. 
countries to go even further in ensuring maternity leave periods of at least 18 weeks (Recommendation No. 191). ${ }^{6}$ Moreover, two other maternity-specific conventions of the International Labour Organization (ILO) (No. 3 of $1919^{7}$ and No. 103 of 1952 ${ }^{8}$ ) provide for a compulsory leave period of six weeks after childbirth, during which the mother must not be allowed to work.

In terms of compliance with Convention No. 183 on duration of maternity leave, only 19 countries in Asia and the Pacific provide paid maternity leave that exceeds 14 weeks (98 days). Furthermore, only 12 countries adhere to Recommendation No. 191 by providing at least 18 weeks (126 days).

In conformity with Convention No. 183, the cash benefits paid during maternity leave should be at least two thirds of a woman's previous earnings. Of the countries in Asia and the Pacific that mandate paid maternity leave, 29 pay 100 per cent of average wages, 10 provide less than 100 per cent and three pay less than the recommended two thirds.

It is important to bear in mind that the coverage of workers by maternity protection provisions depends on various factors, including the extent to which the law is actually implemented, and consequently, the share of the legally protected population which benefits from its application. Annex II provides estimates of the proportion of women receiving maternity benefits in countries of Asia and the Pacific with available data. On average, countries in the region cover only approximately 33.4 per cent of women giving birth for cash maternity benefits.

Most maternity cash benefit schemes and employer liability provisions cover primarily women in formal employment. Several countries, however, are beginning to adjust their legal frameworks to extend maternity protection coverage to certain categories of workers in the informal economy, and, in so doing, facilitate their transition to the formal economy. They have also taken measures to overcome the financial and administrative barriers that have stood in the way of covering these categories of previously uncovered workers.

Mongolia, for instance, provides universal maternity protection coverage through a combination of mechanisms. Formal employees are covered by social insurance on a mandatory basis and receive a replacement rate of 100 per cent of their covered wage for four months. Herders, self-employed and workers in the informal economy can join the scheme on a voluntary basis and receive maternity cash benefits for four

6 R191 - Maternity Protection Recommendation, 2000 (No. 191), 88th ILC session, 15 June 2000.

C003 - Maternity Protection Convention, 1919 (No. 3), 1st ILC session, 29 November 1919.

C103 - Maternity Protection Convention (Revised), 1952 (No. 103), 35th ILC session, 28 June 1952. 
months at a replacement rate of 70 per cent of their selected reference wage after 12 months of contributions. In addition, maternity cash benefits under the Social Welfare Scheme are provided to all pregnant women and mothers of infants regardless of their contribution to the social insurance scheme, status in employment or nationality. Since 2007, the benefits are delivered through one stop shops, a unified service delivery system, including social welfare, social insurance, employment counselling and civil registration. To meet the needs of rural and nomad women, all of the country's provinces and most districts have one stop shops, and a mobile one stop shop van is provided for residents in particularly remote areas (ILO, 2016a; 2016b).

Accordingly, it is hoped that the findings of the present paper will influence Governments to learn from the experience of Mongolia and other countries in ensuring maternity benefits coverage for all women workers, in both the formal and informal sectors.

\section{EXAMINING PAID MATERNITY LEAVE AND CHILD MORTALITY IN ASIA AND THE PACIFIC}

Although the mortality rate for children under five years in Asia and the Pacific has fallen by more than 50 per cent since $2000,{ }^{9}$ millions of infants and children still die each year from preventable causes, and a notable proportion of these deaths take place in low- and middle-income countries of the region. Building on the context set out above, the objective of this section is to probe further into examining the association between paid maternity leave and child health outcomes in Asia and the Pacific.

There is evidence that supports the hypothesis that more generous maternity leave has significant development benefits, in particular when referring to infant mortality and health outcomes (Fallon, Mazar and Swiss, 2017; Nandi and others, 2016). Little is known, however, about the impact of national maternity leave policies, specifically within the context of Asia and the Pacific.

Accordingly, a fixed effects model is used to evaluate whether paid maternity leave affects infant ${ }^{10}$ and under-five mortality rates ${ }^{11}$ in countries representing the five subregions of Asia and the Pacific (South and South-West Asia, North and Central Asia, South-East Asia, East and North-East Asia, and the Pacific).

9 Authors' calculations based on the ESCAP Statistical Database. Available from www.data.unescap. org/escap_stat/ (accessed 20 June 2018).

10 Infant mortality rate is the number of infants dying before reaching one year of age, per 1,000 live births in a given year.

11 Under-five mortality rate is the probability per 1,000 that a newborn baby will die before reaching age of five, if subject to age-specific mortality rates of the specified year. 


\section{Data}

Through a dataset based on publicly available statistics on paid maternity leave complemented with narrative evidence of the dates when legislative changes were enacted, paid maternity leave between 1991 and 2016 in 34 Asia-Pacific countries is examined for this paper using complete data available for this time period. ${ }^{12}$

Data on maternity leave are collected from the Women, Business and the Law database of the World Bank and through narrative evidence on legislative changes from the NATLEX and Working Conditions Laws databases of ILO. Further details on the legislative provisions related to the duration of maternity leave in these countries are provided in annex I.

Data on infant and under-five mortality, immunization rates and health expenditures are collated from the Health Nutrition and Population Statistics database of the World Bank. In addition, data on average years of schooling are retrieved from the Global Educational Attainment dataset provided by the Institute for Health Metrics and Evaluation. The remaining data are primarily obtained through the World Development Indicators database of the World Bank.

The main policy variable of interest is the duration of paid maternity leave (in days) and the outcome variables of interest are the mortality rates of children - in their first year (infant) and under the age of five years. The potentially moderating effects of immunization rates, education, health expenditures, and other economic and development factors are controlled for.

Figure 1 shows a plot of the average duration of maternity leave (in days) in Asia and the Pacific from 1991 to 2016. Aside from the overall increase in the duration of maternity leave in the region, the graph shows that upper-middle income countries have generally maintained the longest maternity leaves across this time period. This can partly be explained by the inclusion in this income group of the country with the longest maternity leave in the region (Islamic Republic of Iran, 270 days) and former Soviet countries, Azerbaijan and the Russian Federation, which place a strong emphasis on social protection and maternity protection provisions.

12 Data on duration of maternity leave from 1991 to 2016 are not available for the following economies: Democratic People's Republic of Korea; Georgia; Kazakhstan; Kiribati; Maldives; Marshall Islands; Micronesia (Federated States of); Palau; Samoa; Timor-Leste; Tonga; Turkmenistan; Tuvalu; American Samoa; Cook Islands; French Polynesia; Guam; Hong Kong, China; Macao, China; Nauru; New Caledonia; Niue; and Northern Mariana Islands. 
Figure 1. Duration of maternity leave in Asia and the Pacific, 1991-2016

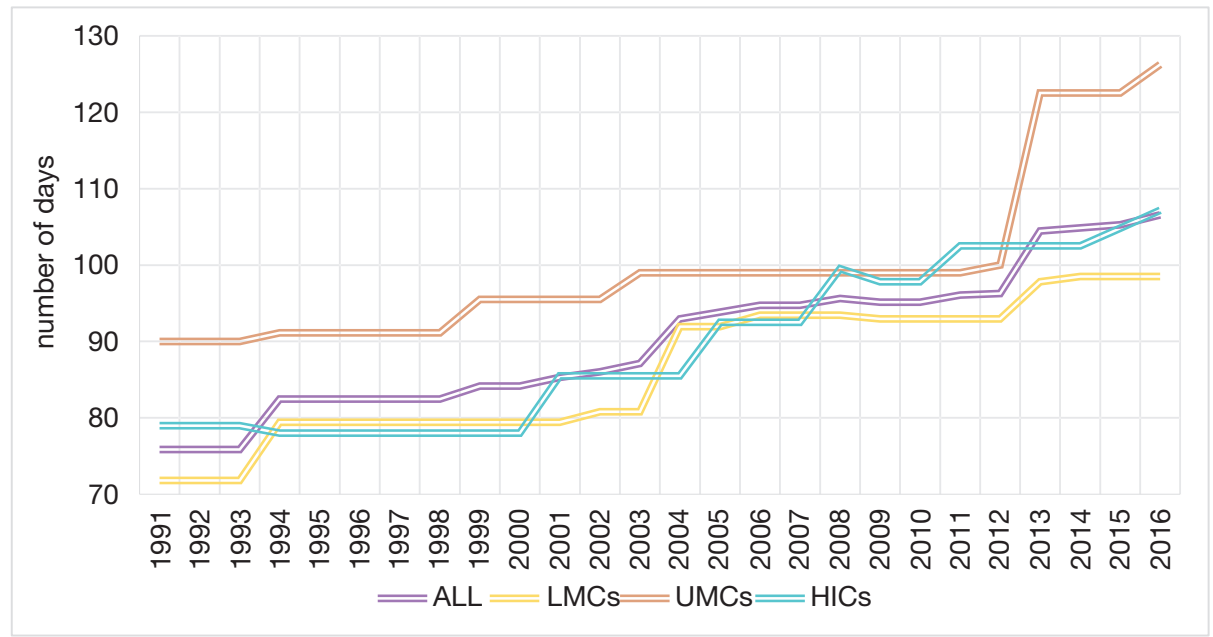

Source: Women, Business and the Law 2018 database, and World Development Indicators database. Available at https://databank.worldbank.org/source/world-development-indicators.

Note: All, full sample; LMCs, low- and lower-middle income; UMCs, upper-middle income; HICs, high-income countries.

As illustrated in figures 2 and 3, there have been marked improvements in reducing infant and under-five mortality rates in Asia and the Pacific, with a decline of more than fifty per cent in both cases. A closer look through a granular lens, however, shows that progress has been heterogeneous across countries: for instance, Afghanistan (low-income) and Pakistan (lower-middle income) still have high levels of infant and under-five mortality, which have been stagnating in recent years. 
Figure 2. Infant mortality rates in Asia and the Pacific, 1991-2016

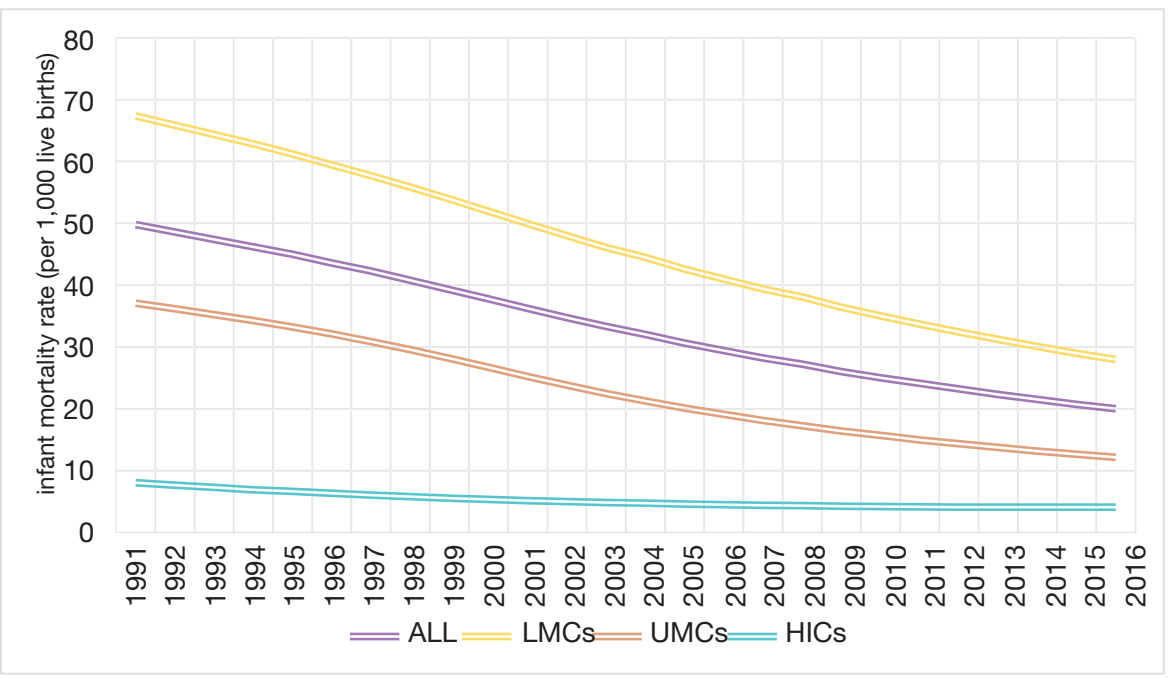

Source: World Bank Health Nutrition and Population Statistics database. Available at https://databank.worldbank. org/source/health-nutrition-and-population-statistics.

Note: All, full sample; LMCs, low- and lower-middle income; UMCs, upper-middle income; HICs, high-income countries.

Figure 3. Under-five mortality rates in Asia and the Pacific, 1991-2016

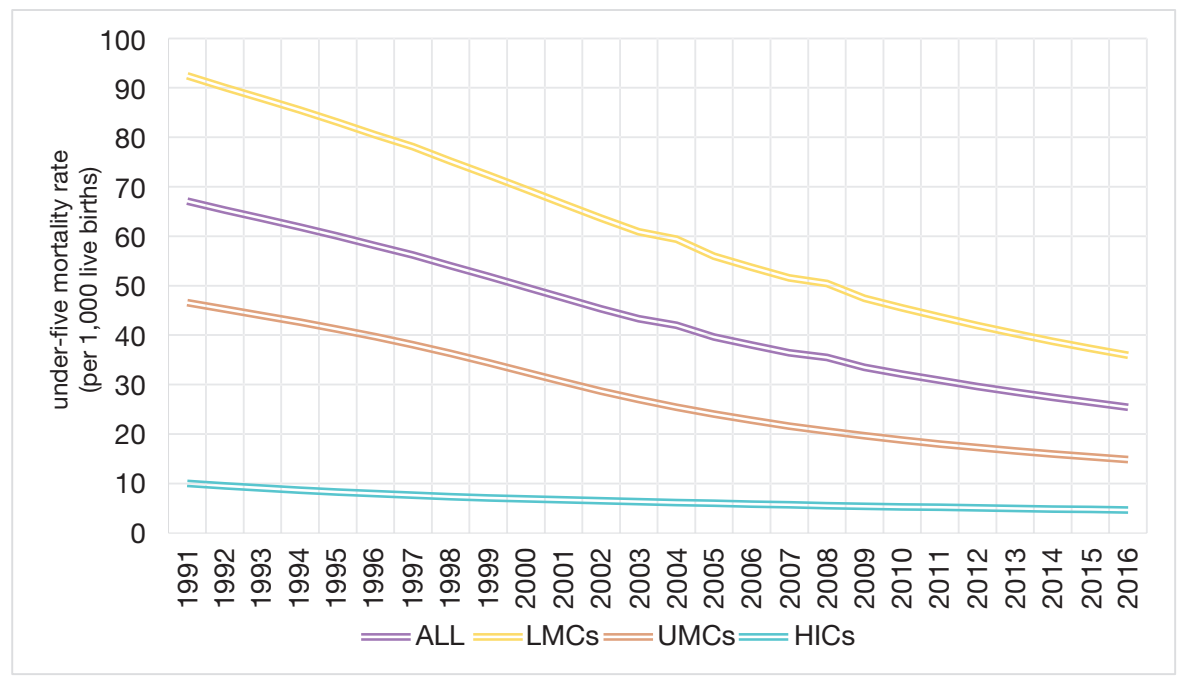

Source: World Bank Health Nutrition and Population Statistics database. Available at https://databank.worldbank. org/source/health-nutrition-and-population-statistics.

Note: All, full sample; LMCs, low- and lower-middle income; UMCs, upper-middle income; HICs, high-income countries. 


\section{Table 1. Descriptive statistics}

\begin{tabular}{|c|c|c|c|c|c|c|c|c|}
\hline Variable & $\begin{array}{l}\text { Mean } \\
\text { (AII) }\end{array}$ & $\begin{array}{l}\text { Std. } \\
\text { Dev. } \\
\text { (All) }\end{array}$ & $\begin{array}{l}\text { Mean } \\
\text { (LMCs) }\end{array}$ & $\begin{array}{l}\text { Std. } \\
\text { Dev. } \\
\text { (LMCs) }\end{array}$ & $\begin{array}{l}\text { Mean } \\
\text { (UMC) }\end{array}$ & $\begin{array}{l}\text { Std. } \\
\text { Dev. } \\
\text { (UMCs) }\end{array}$ & $\begin{array}{l}\text { Mean } \\
\text { (HICs) }\end{array}$ & $\begin{array}{l}\text { Std. } \\
\text { Dev. } \\
\text { (HICs) }\end{array}$ \\
\hline \multicolumn{9}{|c|}{ Policy variable } \\
\hline $\begin{array}{l}\text { Paid } \\
\text { maternity } \\
\text { leave (days) }\end{array}$ & 92.32 & 31.95 & 88.67 & 32.84 & 101.07 & 34.74 & 91.46 & 18.63 \\
\hline \multicolumn{9}{|c|}{ Dependent variables } \\
\hline $\begin{array}{l}\text { Mortality } \\
\text { rate, infant } \\
\text { (per } 1000 \\
\text { live births) }\end{array}$ & 33.67 & 25.73 & 46.37 & 24.07 & 23.23 & 15.60 & 5.24 & 2.42 \\
\hline $\begin{array}{l}\text { Mortality } \\
\text { rate, under-5 } \\
\text { (per } 1000 \\
\text { live births) }\end{array}$ & 44.20 & 36.34 & 61.82 & 35.41 & 28.37 & 19.64 & 6.59 & 3.09 \\
\hline \multicolumn{9}{|c|}{ Control Variables } \\
\hline $\begin{array}{l}\text { Average } \\
\text { years of } \\
\text { schooling } \\
\text { per capita, } \\
\text { female }\end{array}$ & 8.46 & 3.51 & 6.85 & 3.19 & 9.33 & 2.13 & 12.71 & 1.36 \\
\hline $\begin{array}{l}\text { Immunization, } \\
\text { DPT (\% of } \\
\text { children } \\
\text { ages 12-23 } \\
\text { months) }\end{array}$ & 83.99 & 16.11 & 78.17 & 17.86 & 91.99 & 8.70 & 92.66 & 6.01 \\
\hline $\begin{array}{l}\text { Current } \\
\text { health } \\
\text { expenditure } \\
\text { (\% of GDP) }\end{array}$ & 4.92 & 2.14 & 4.67 & 2.09 & 4.58 & 1.17 & 6.21 & 2.78 \\
\hline $\begin{array}{l}\text { Log GDP per } \\
\text { capita }\end{array}$ & 8.78 & 1.14 & 8.39 & 0.98 & 9.31 & 0.91 & 9.33 & 1.37 \\
\hline
\end{tabular}

Note: All, full sample; LMCs, low- and lower-middle income; UMCs, upper-middle income; HICs, high-income countries. The number of observations for the dependent variables is 884 for the full sample, 520 for LMCs, 208 for UMCs and 156 for HICs.

\section{Empirical methodology}

Political and economic structures can change over time. Various country-specific characteristics can influence paid maternity leave policies and infant or under-five mortality, but all of these factors may not be fully measurable in the dataset. For panel data, a random effects model or a fixed effects model can be used to measure the effect of changes on an outcome variable. A random effects model assumes 
no correlation between the error terms and explanatory variables. In cases in which a number of unobserved time-invariant factors are assumed to be correlated with explanatory variables, a fixed effects model is preferred, as it controls all the unobserved time-invariant characteristics and makes the estimated coefficient less likely to be biased. As various unobserved country-specific characteristics, such as policy and economic structures, culture, religion, and social norms, are assumed to be correlated with child mortality, a fixed effects model is used. The Hausman test confirms the correlation between unobserved time-invariant effects and explanatory variables.

By integrating existing data that contain variables of interests, such as maternity leave, child mortality, immunization rates, health expenditure, education, and other country-specific characteristics, a potentially important research question can be addressed at a low cost. Various socioeconomic, political and cultural factors that may or may not change over time are expected to affect the explanatory variables and the outcome variable. Under the assumption that unobserved time-invariant factors are correlated with explanatory variables, a fixed effects model is used to examine the causes of changes. One drawback in using a fixed effects model with existing data might be that all the time-variant variables cannot be controlled. Inclusion of other observed time-variant variables may partially address this issue, but at the same time, it is necessary to be cautious, as it may increase the errors in the model.

Similar to specification of Aslim, Panovska and Tas (2019), the model is defined as follows:

$$
y_{i t}=\alpha_{i}+\beta M L_{i t}+\gamma X_{i t}+\rho_{t}+\varepsilon_{i t}
$$

where $y_{i t}$ is the infant or under-five mortality measure of interest for country $i$ at year $t$. The policy variable of interest is $M L_{i t}$ which captures paid maternity leave in terms of days for country $i$ at year $t$. Control variables, denoted as $X_{i t}$, include immunization rates, female average years of schooling (15 to 44 years of age), and health expenditures (\% of gross domestic product (GDP)). The percentage of children aged 12 to 23 months immunized for diphtheria, pertussis, and tetanus is used as a variable in the under-five mortality models because of the significant number of vaccine-preventable deaths. The variables on schooling and health expenditures reflect the differences in institutional structures across markets. Average years of schooling and health expenditures are used as a proxy for education and health trends at the aggregate level, respectively. Log GDP per capita is also included to account for economic development. Year and country fixed effects are captured by $\rho_{t}$ and $\alpha_{i}$, respectively. The error term is $\varepsilon_{i t^{*}}$. The objective of this fixed effects model is to estimate the coefficient $\beta$ of the maternity leave policy variable. 


\section{Results}

Tables $2 \mathrm{a}$ and $2 \mathrm{~b}$ provide the estimates for all countries of the correlation between paid maternity leave and the mortality rates of infants and children under five years old. The countries are separated into three groups by level of income, as classified by the World Bank: ${ }^{13}$ (i) low- and lower-middle income (LMCs); (ii) upper-middle income (UMCs); and (iii) high-income (HICs)..$^{14}$

\section{Table 2a. Estimating the correlation between paid maternity leave and infant mortality in Asia and the Pacific}

\begin{tabular}{|c|c|c|c|c|}
\hline & $\begin{array}{l}\text { All } \\
\text { (1) }\end{array}$ & $\begin{array}{l}\text { LMCs } \\
\text { (2) }\end{array}$ & $\begin{array}{l}\text { UMCs } \\
\text { (3) }\end{array}$ & $\begin{array}{l}\text { HICs } \\
\text { (4) }\end{array}$ \\
\hline \multicolumn{5}{|l|}{ Policy variable } \\
\hline \multirow[t]{2}{*}{ Maternity leave } & $-0.0249^{\star *}$ & -0.0521 & $-0.0169^{\star}$ & $0.0115^{*}$ \\
\hline & $(0.00938)$ & $(0.0276)$ & (0.00792) & $(0.00533)$ \\
\hline \multicolumn{5}{|l|}{ Control variables } \\
\hline \multirow[t]{2}{*}{ Immunization } & $-0.201^{\star \star \star}$ & $-0.199^{\star \star \star}$ & $-0.204^{\star \star \star}$ & 0.00947 \\
\hline & $(0.0275)$ & $(0.0337)$ & $(0.0495)$ & $(0.0146)$ \\
\hline \multirow[t]{2}{*}{ Health expenditures } & $0.720^{\star \star \star}$ & $0.600^{*}$ & $-1.144^{\star \star \star}$ & $-0.318^{* * *}$ \\
\hline & $(0.196)$ & $(0.269)$ & $(0.308)$ & $(0.0889)$ \\
\hline \multirow[t]{2}{*}{ Schooling } & $14.95^{\star \star \star}$ & $12.14^{\star \star \star}$ & $19.22^{\star \star *}$ & -0.777 \\
\hline & $(1.171)$ & $(1.566)$ & (3.522) & $(0.563)$ \\
\hline \multirow[t]{2}{*}{ Log GDP } & $-17.30^{\star \star \star}$ & $-15.88^{\star \star \star}$ & $-16.88^{\star \star \star}$ & $-4.600^{\star \star *}$ \\
\hline & $(1.291)$ & $(2.672)$ & $(1.172)$ & $(0.572)$ \\
\hline Year & FE & FE & FE & FE \\
\hline$N$ & 493 & 289 & 128 & 76 \\
\hline $\mathrm{R}^{2}$ overall & 0.381 & 0.205 & 0.147 & 0.0845 \\
\hline $\mathrm{R}^{2}$ within & 0.831 & 0.855 & 0.929 & 0.889 \\
\hline $\mathrm{R}^{2}$ between & 0.494 & 0.367 & 0.116 & 0.223 \\
\hline
\end{tabular}

Note: $\quad$ All of the specifications include country fixed effects.

Standard errors are in parentheses.

Significance levels are: ${ }^{\star} 0.05 ;{ }^{\star \star} 0.01 ;{ }^{\star \star \star} 0.001$.

All, full sample; LMCs, low- and lower-middle income countries; UMCs, upper-middle income countries; HICs, high-income countries; FE, fixed effects.

${ }^{13}$ An explanation of World Bank's country classifications by income level is available at: http://blogs. worldbank.org/opendata/new-country-classifications-2016.

14 Please refer to annex I for the income group categorizations (as per the World Bank) of each country in the sample. 


\section{Table 2b. Estimating the correlation between paid maternity leave and under-five mortality in Asia and the Pacific}

\begin{tabular}{|c|c|c|c|c|}
\hline & $\begin{array}{l}\text { All } \\
\text { (1) }\end{array}$ & $\begin{array}{l}\text { LMCs } \\
\text { (2) }\end{array}$ & $\begin{array}{l}\text { UMCs } \\
\text { (3) }\end{array}$ & $\begin{array}{c}\text { HICs } \\
\text { (4) }\end{array}$ \\
\hline \multicolumn{5}{|l|}{ Policy variable } \\
\hline \multirow[t]{2}{*}{ Maternity leave } & $-0.0291^{*}$ & -0.0656 & $-0.0238^{\star \star}$ & $0.0168^{\star}$ \\
\hline & $(0.0136)$ & $(0.0408)$ & $(0.00859)$ & $(0.00692)$ \\
\hline \multicolumn{5}{|l|}{ Control variables } \\
\hline \multirow[t]{2}{*}{ Immunization } & $-0.294^{\star \star \star}$ & $-0.301^{\star \star \star}$ & $-0.174^{\star *}$ & 0.0142 \\
\hline & $(0.0398)$ & $(0.0497)$ & $(0.0537)$ & $(0.0190)$ \\
\hline \multirow[t]{2}{*}{ Health expenditures } & $1.111^{* * *}$ & 0.756 & $-1.265^{\star * \star}$ & -0.160 \\
\hline & $(0.283)$ & $(0.396)$ & $(0.334)$ & $(0.115)$ \\
\hline \multirow[t]{2}{*}{ Schooling } & $23.76^{\star \star \star}$ & $20.28^{\star \star \star}$ & $22.44^{\star \star \star}$ & -0.673 \\
\hline & (1.698) & (2.310) & (3.819) & $(0.731)$ \\
\hline \multirow[t]{2}{*}{ Log GDP } & $-21.53^{\star \star \star}$ & $-25.74^{\star \star \star}$ & $-20.45^{\star \star \star}$ & $-3.732^{\star \star \star}$ \\
\hline & $(1.871)$ & (3.940) & $(1.270)$ & $(0.742)$ \\
\hline Year & FE & FE & FE & FE \\
\hline$N$ & 493 & 289 & 128 & 76 \\
\hline $\mathrm{R}^{2}$ overall & 0.443 & 0.244 & 0.131 & 0.108 \\
\hline $\mathrm{R}^{2}$ within & 0.816 & 0.846 & 0.941 & 0.869 \\
\hline $\mathrm{R}^{2}$ between & 0.557 & 0.395 & 0.0971 & 0.283 \\
\hline
\end{tabular}

Note: $\quad$ All of the specifications include country fixed effects.

Standard errors are in parentheses.

Significance levels are: ${ }^{*} 0.05 ;{ }^{* *} 0.01 ;{ }^{* \star *} 0.001$.

All, full sample; LMCs, low- and lower-middle income countries; UMCs, upper-middle income countries; HICs, high-income countries; FE, fixed effects.

The results show that in the case of infant mortality, there is an overall association of paid maternity leave with lower mortality in Asia-Pacific countries. Among all countries, a one-day increase in paid maternity leave reduces the infant mortality rate by 0.0249 deaths per 1,000 live births $(p<0.01)$. This is equivalent to 1.494 fewer deaths for every paid maternity leave of 60 days. The coefficient and the significance levels are lower in upper-middle income countries. The results are not statistically significant for low- and lower-middle income countries. Notably, immunization rates show a significant association with reduced infant mortality in most countries.

In the case of under-five mortality, national guarantees of paid maternity leave are associated with lower child mortality, with 5 per cent statistical significance. For instance, the under-five mortality rate decreases by 0.0291 deaths per 1,000 live births 
for an additional day of paid maternity leave. The statistical significance increases to the 1 per cent level in upper-middle income countries. This association is observed even after controlling for countries' immunization rates, health expenditures as a percentage of GDP, female years of schooling and log GDP per capita.

In high-income countries, paid maternity leave may be a less significant factor in relation to either infant or under-five mortality, as such leave has been mandated for several decades in most cases and accordingly, other factors are likely to be now playing a greater role. These include birth defects and chromosomal abnormalities, injuries and conditions in mothers that also affect their children.

Analyses to assess the robustness of the results are also conducted. A dummy variable that takes a value of 1 if a country has a maternity leave policy in a given year $t$ and 0 if it does not. The main findings appear to be relatively robust to this alternative model specification. The results are consistent with the main results in terms of the association between maternity policy and infant and under-five mortality. The full set of results for the robustness checks is presented in annex III.

\section{Discussion}

The results indicate that national guarantees of paid maternity leave are generally associated with lower under-five mortality in countries of Asia and the Pacific. They also show that the less statistically significant results in relation to infant mortality suggest the need for further investigation on child health and development processes.

The overall findings are consistent with other research findings that support the importance of paid maternity leave to promote positive child health outcomes. For working mothers, maternity leave greatly enhances the probability of initiating and continuing breastfeeding for a healthy period of time (Yilmaz and other, 2002). In fact, the World Health Organization (WHO) recommends a minimum of six months of exclusive breastfeeding to achieve optimal growth, development and health benefits. ${ }^{15}$ In addition, prior studies have also indicated that conflict between working hours of parents and the hours when immunizations are offered can lead to delays in attaining or neglect of much needed vaccinations (McCormick and others, 1997). Parental care is also especially important during the early months to ensure that the child receives the requisite nutrition and is raised in a setting where there is adequate sanitation (Nandi and others, 2016).

In addition, paid maternity leave has been shown to lead to positive outcomes for mothers, which indirectly may help reduce child mortality. Women who receive paid

15 Details on the World Health Organization's infant feeding recommendation are available from www. who.int/nutrition/topics/infantfeeding_recommendation/en/index.html. 
maternity leave not only have increased their income available during a critical time, but they are also more likely to stay employed after the child's birth and not suffer a long-term wage penalty (Waldfogel, Higuchi and Abe, 1999). Paid parental leave also enables women to physically, mentally and emotionally recover from childbirth. For instance, studies have found that the availability of leave reduces the risk of postpartum depression (Chatterji and Markowitz, 2012). Across the spectrum of physical and emotional health, the length of leave is likely to make a substantial difference. According to some studies, it is only after at least 12 weeks of post-partum leave that mothers' self-reported measures of vitality and physical health typically begin to improve (Dagher, McGovern and Dowd, 2014).

Despite the growing body of evidence that underscores the manifold benefits of maternity leave, there continues to be persistent obstacles to accessing maternity protection and barriers to implementing such policies in many countries across Asia and the Pacific. Eligibility criteria for maternity leave in many countries are often too restrictive to achieve universal protection. ILO estimates that approximately 15.6 million female domestic workers worldwide are not legally entitled to maternity leave (Addati, Cassirer and Gilchrist, 2014). Self-employed women, agricultural, casual or temporary workers, and migrants are also frequently excluded.

A key area of concern is that despite progressive legislation on paid maternity leave, the issue of financing these benefits still remains a challenge. For instance, in March 2017, the Parliament of India passed amendments to the Maternity Benefit Act, thereby granting women working in the formal sector a paid maternity leave of 26 weeks (182 days), an increase from the previous duration of 12 weeks ( 84 days). It should be noted, however, that as the employer is liable to pay these benefits, some critics argue that the policy could act as a disincentive to hire women. In addition, the disparity between the cost of hiring women compared to men may also lead employers to reduce women's salaries to compensate for paying higher maternity leave benefits (Nikore, 2017).

There are a number of different methods of funding maternity cash benefits during maternity leave. The most commonly employed sources of funding in Asia and the Pacific are the following: employment-related social insurance (contributory schemes); the employer through the direct payment of maternity benefits (employer liability); and a combination of the two methods (mixed system). Less frequently employed are maternity benefits paid out of public funds (non-contributory schemes), which can finance maternity benefits individually or in conjunction with social insurance or the employers.

A shift from systems relying entirely on employer liability to more mixed systems has often proven to be more sustainable (Addati, Cassirer and Gilchrist, 2014). Finding 
viable collective ways of financing maternity benefits without placing undue financial costs on the employer is essential to achieving effective maternity protection and gender equality at work. It should, therefore, become a priority in shaping policy.

Moreover, legislated paternity leave is a pivotal instrument to encourage men to take a greater role in childcare while promoting women's career advancement. Such policies may include, among others, incentives to encourage men to use their legal entitlements to paternity or parental leave. In some countries, such as Portugal, bonuses are used to extend the total length of paid parental leave if it is shared among both parents (OECD, 2015). Sweden and Iceland have introduced a paternity leave scheme that can only be taken by the father and cannot be transferred to the mother, which has led to an increase in the number of fathers taking paternity leave (OECD, 2015). A study on the Quebec Parental Insurance Program in Canada, which improved compensation and reserved five weeks of leave for fathers, indicate that it greatly increases the rates at which fathers take leave and has made housework more gender-equal (Patnaik, 2019). This indicates that setting aside non-transferable leave specifically for fathers encourages the use of such leave. The knock-on effects include reducing the stigma of taking leave to spend time with the family, boosting positive labour market outcomes for women and creating a long-lasting change in patterns of behaviour at home.

Furthermore, some countries, such as Australia and New Zealand, are also dropping the distinction between maternity and paternity leave - opting instead for parental leave, which can be shared between the parents as they choose. Advocates argue that this gender-neutral approach is valuable in transforming traditional gender roles at home and in childcare.

\section{POLICY RECOMMENDATIONS}

The findings of the study reinforce the importance of increasing the adoption and availability of paid family leave to working parents across Asia and the Pacific. In this regard, the following priority areas of action for Governments in the Asia-Pacific region are recommended:

\section{- Adopting and implementing inclusive laws and policies}

Access to effective protection rests on labour legislation, policies and regulations that enshrine the right to maternity protection and work-family balance for all working women and men, including self-employed, informal, domestic and agricultural workers and those with non-standard contracts, without any discrimination. Greater efforts are also needed in raising awareness among employers and workers of maternity protection rights and through investing in monitoring and enforcement mechanisms. 
Furthermore, improving data collection to measure the effective coverage of maternity protection legislation and its outcomes requires increased attention.

- Ensuring adequate wage replacement provisions

In accordance with international legal standards, the cash benefits paid during maternity leave should be at least two thirds of the employee's previous salary, and for a period of not less than 14 weeks or preferably 18 weeks. This benefit should ideally be paid by social insurance or public funds at minimal or no cost to employers, in combination with public support measures and incentives, which especially target women in the informal sector, who are often left behind.

- Preventing and eliminating discrimination against women and men with family responsibilities

A comprehensive approach to preventing and combating the multiple forms of discrimination based on maternity and family responsibilities, including in relation to recruitment, retention and promotion, requires the establishment of adequate antidiscrimination frameworks supported by specialized authorities. Periodic review of anti-discrimination frameworks, enhanced guidance to employers and workers on how to comply, and collection and publication of data on discrimination based on family responsibilities increases accountability and public awareness of this issue. In addition, transforming discriminatory social norms by encouraging a shift towards a model in which men act as active co-parents is also crucial.

- Fostering continued research and data collection to inform evidence-based policies

Further research is essential to explore the mechanisms through which nationallevel family leave policies affect infant and child mortality and related development outcomes. Governments may wish to consider collaboration with academic institutes or United Nations entities to capitalize on emerging research in this area. One potential topic of interest is examining the impact of leave available specifically for parents to meet their children's health needs, including for vaccination appointments or to seek medical care.

Another critical area of research is the obstacles facing countries in adopting maternity leave. An often-cited concern by developing countries is the costs of maternity benefits. One approach would be to look at the costs of social security more generally and consider the costs of maternity protection benefits. According to ILO calculations, a minimum package of social security is not only affordable and feasible even in the poorest countries, but it is conducive to social and economic development. Studies show that the initial gross annual cost (excluding access to 
basic health care that it is already financed to some extent) is estimated to be in the range of 2.2 to 5.7 per cent of GDP (Pal and others, 2005). With respect to maternity cash and medical benefits in particular, the cost of financing maternity protection is low relative to other forms of social security and in most contexts, it is possible to finance a social insurance scheme providing cash maternity benefits for less than 0.7 per cent of covered wages. ${ }^{16}$

When discussing affordability, it is also important to assess and contrast the costs of not providing adequate maternity protection, which include increased poverty, inequality and social exclusion resulting from the poor health or even death of women and children. Stenberg and others (2014) show that increasing health expenditures by just US $\$ 5$ per person per year up to 2035 in 74 highly affected countries could yield up to nine times that value in economic and social benefits.

\section{CONCLUSION}

The findings of the present paper suggest that paid maternity leave across the Asia-Pacific region could make a substantial difference in reducing child mortality. While maternity protection standards have been gradually improving in the AsiaPacific region, the duration of leave available to women, and the amount of benefits, source of funding and coverage varies markedly among countries. The region still has a way to go in ensuring that all countries adhere to ILO Recommendation No. 191 by providing a minimum of 18 weeks of paid leave or ensuring an adequate wage replacement rate.

Beyond maternal and infant health, maternity leave can also contribute towards increased income security, promote employment continuity and advance gender equality in the workforce and the household. Nevertheless, in the context of a burgeoning informal economy in Asia and the Pacific in which women are distinctly overrepresented, further efforts are needed to extend coverage of maternity leave and benefits to women workers in the informal sector. It is hoped, therefore, that the findings of this paper encourage Governments to not only ensure the legal provision of paid maternity leave but to also extend much-needed maternity protection coverage to women workers in the informal economy. Through leaving no woman and child behind, the Asia-Pacific region will be able to make strides towards realizing the vision of the 2030 Agenda for Sustainable Development to achieve an inclusive future for all.

${ }^{16}$ Based on data from the United States Social Security Administration and social security programmes around the world. 


\section{Annex I}

Table A.1. Duration of paid maternity leave in countries of Asia and the Pacific (with available data)

\begin{tabular}{|c|c|c|c|c|}
\hline & Country & Income group & $\begin{array}{l}\text { Length } \\
\text { of paid } \\
\text { maternity } \\
\text { leave } \\
\text { (days) }\end{array}$ & $\begin{array}{c}\text { Legislative provisions for duration } \\
\text { of maternity leave and year of its } \\
\text { enactment/amendment }\end{array}$ \\
\hline 1 & Afghanistan & Low-income & 90 & 2007: The Labour Code, Article 54 (1) \\
\hline 2 & Armenia & $\begin{array}{l}\text { Lower-middle } \\
\text { income }\end{array}$ & 140 & 2004: Labour Code, Article 172 \\
\hline 3 & Australia & High-income & 126 & $\begin{array}{l}\text { 2009: Fair Work Act, Division 5, Part } \\
\text { 2-2, Chapter } 2 \\
\text { 2010: Paid Parental Leave Act, Part 21, } \\
\text { Division 2, } 11\end{array}$ \\
\hline 4 & Azerbaijan & $\begin{array}{l}\text { Upper-middle } \\
\text { income }\end{array}$ & 126 & 1999: Labour Code, Article 125 \\
\hline 5 & Bangladesh & $\begin{array}{l}\text { Lower-middle } \\
\text { income }\end{array}$ & 112 & $\begin{array}{l}\text { 1939: Maternity Benefits Act } \\
\text { 2006: Labour Act, Articles 45, 47(3) }\end{array}$ \\
\hline 6 & $\begin{array}{l}\text { Brunei } \\
\text { Darussalam }\end{array}$ & High-income & 91 & 2009: Employment Order, Article 91(1) \\
\hline 7 & Cambodia & $\begin{array}{l}\text { Lower-middle } \\
\text { income }\end{array}$ & 90 & 1997: Labour Law, Article 182 \\
\hline 8 & China & $\begin{array}{l}\text { Upper-middle } \\
\text { income }\end{array}$ & 128 & $\begin{array}{l}\text { 1988: Regulations Governing Labour } \\
\text { Protection for Female Staff Members } \\
\text { and Workers, Article } 8 \\
\text { 1994: Labour Law, Article } 62 \\
\text { 2012: Order of the State Council No. } \\
\text { 619, Special Rules on the Labour } \\
\text { Protection of Female Employees, } \\
\text { Article } 7 \\
\text { 2016: Revised Provincial Family } \\
\text { Planning Regulations }\end{array}$ \\
\hline 9 & Fiji & $\begin{array}{l}\text { Upper-middle } \\
\text { income }\end{array}$ & 84 & $\begin{array}{l}\text { 2007: Employment Relations } \\
\text { Promulgation, Article } 101 \\
\text { 2018: National Budget }\end{array}$ \\
\hline 10 & India & $\begin{array}{l}\text { Lower-middle } \\
\text { income }\end{array}$ & 182 & $\begin{array}{l}\text { 1961: Maternity Benefit Act, } \\
\text { Article 6(2), (4) } \\
\text { 2017: Maternity Benefit (Amendment) } \\
\text { Act }\end{array}$ \\
\hline 11 & Indonesia & $\begin{array}{l}\text { Lower-middle } \\
\text { income }\end{array}$ & 90 & $\begin{array}{l}\text { 1989: Law No.1, Labour Law, } \\
\text { Article 13(2) } \\
\text { 2003-2016: Act No. 13, Manpower Act, } \\
\text { Article 82(1) }\end{array}$ \\
\hline
\end{tabular}


Table A.1. (continued)

\begin{tabular}{|c|c|c|c|c|}
\hline & Country & Income group & $\begin{array}{l}\text { Length } \\
\text { of paid } \\
\text { maternity } \\
\text { leave } \\
\text { (days) }\end{array}$ & $\begin{array}{c}\text { Legislative provisions for duration } \\
\text { of maternity leave and year of its } \\
\text { enactment/amendment }\end{array}$ \\
\hline 12 & $\begin{array}{l}\text { Iran (Islamic } \\
\text { Republic of) }\end{array}$ & $\begin{array}{l}\text { Upper-middle } \\
\text { income }\end{array}$ & 270 & $\begin{array}{l}\text { 1990: Labour Code, Article } 76 \\
\text { 1995: Encouraging Breastfeeding and } \\
\text { Protection of Breastfeeding Mothers } \\
\text { Law, Article } 3 \\
\text { 2013: Amendment to Family and } \\
\text { Population Control Regulations Act, } \\
\text { Article } 2\end{array}$ \\
\hline 13 & Japan & High-income & 98 & $\begin{array}{l}\text { 1947: Labour Standards Act, Article } \\
\text { 65(1)(2) } \\
\text { 1991: Act on the Welfare of Workers } \\
\text { Who Take Care of Children or Other } \\
\text { Family Members Including Child Care } \\
\text { and Family Care Leave, Articles 5, 6, } \\
\text { 7, 9 } \\
\text { 1991: Ordinance for Enforcement of } \\
\text { the Act on the Welfare of Workers Who } \\
\text { Take Care of Children and Other Family } \\
\text { Members, Articles 4-2, 6, } 7 \\
\text { 1998: National Personnel Authority } \\
\text { Regulation amending NPA Regulation } \\
\text { No. 15-14 (Hours of Work, Holidays and } \\
\text { Leave). No. 15-14-6 }\end{array}$ \\
\hline 14 & Kyrgyzstan & $\begin{array}{l}\text { Lower-middle } \\
\text { income }\end{array}$ & 126 & $\begin{array}{l}\text { 2004: Labour Code of the Republic of } \\
\text { Kyrgyzstan of } 4 \text { August } 2004 \\
\text { 2005: Act No. } 85 \text { of } 30 \text { June } 2005 \\
\text { to amend the Labour Code of the } \\
\text { Republic of Kyrgyzstan (Text No. 643) }\end{array}$ \\
\hline 15 & $\begin{array}{l}\text { Lao People's } \\
\text { Democratic } \\
\text { Republic }\end{array}$ & $\begin{array}{l}\text { Lower-middle } \\
\text { income }\end{array}$ & 105 & $\begin{array}{l}\text { 2006: Labour Law (amended), Article } 39 \\
\text { 2013: Labour Law (amended), Article } 98\end{array}$ \\
\hline 16 & Malaysia & $\begin{array}{l}\text { Upper-middle } \\
\text { income }\end{array}$ & 60 & $\begin{array}{l}\text { 1955: Employment Act, Article 37(1)(a) } \\
\text { and (b) } \\
\text { 1989: (i) Act No. 265, Employment } \\
\text { Act, Article 37(1)(a), (ii) Act No. 265, } \\
\text { Employment Act (with amendments), } \\
\text { Articles 37(1)(a)(i) and 37(1)(d)(ii) }\end{array}$ \\
\hline 17 & Mongolia & $\begin{array}{l}\text { Lower-middle } \\
\text { income }\end{array}$ & 120 & 1999: Labour Law Article 104(1)-(3) \\
\hline 18 & Myanmar & $\begin{array}{l}\text { Lower-middle } \\
\text { income }\end{array}$ & 98 & $\begin{array}{l}\text { 1954: Social Security Act, Chapter VI } \\
\text { 2014: Leave and Holidays Act (1951), } \\
\text { as amended } 2014\end{array}$ \\
\hline
\end{tabular}


Table A.1. (continued)

\begin{tabular}{|c|c|c|c|c|}
\hline & Country & Income group & $\begin{array}{l}\text { Length } \\
\text { of paid } \\
\text { maternity } \\
\text { leave } \\
\text { (days) }\end{array}$ & $\begin{array}{c}\text { Legislative provisions for duration } \\
\text { of maternity leave and year of its } \\
\text { enactment/amendment }\end{array}$ \\
\hline 19 & Nepal & Low-income & 52 & $\begin{array}{l}\text { 1993: Labour Rules, Article } 34 \\
\text { 1993: Civil Service Rules, Article } 59\end{array}$ \\
\hline 20 & New Zealand & High-income & 126 & $\begin{array}{l}\text { 1980: Maternity Leave and Employment } \\
\text { Protection Act } \\
\text { 1987: Parental Leave and Employment } \\
\text { Protection Act (No. 129), Article 9(1) } \\
\text { 2014, 2016, 2017: Parental Leave and } \\
\text { Employment Protection Amendments }\end{array}$ \\
\hline 21 & Pakistan & $\begin{array}{l}\text { Lower-middle } \\
\text { income }\end{array}$ & 84 & $\begin{array}{l}\text { 1958: West Pakistan Maternity Benefit } \\
\text { Ordinance, Article 5(2) } \\
\text { 2013: Khyber Pakhtunkhwa Maternity } \\
\text { Benefits Act [No. XVIII] (provincial) }\end{array}$ \\
\hline 22 & $\begin{array}{l}\text { Papua New } \\
\text { Guinea }\end{array}$ & $\begin{array}{l}\text { Lower-middle } \\
\text { income }\end{array}$ & 0 & --- \\
\hline 23 & Philippines & $\begin{array}{l}\text { Lower-middle } \\
\text { income }\end{array}$ & 60 & $\begin{array}{l}\text { 1989: (i) Republic Act No. 1161, Social } \\
\text { Security Act (ii) Presidential Decree No. } \\
\text { 1202, Amendment to Republic Act No. } \\
\text { 1161, Section 7, (iii) Presidential Decree } \\
\text { No. 1636, Amendment to Republic Act } \\
\text { No. 1161, Section } 11 \\
\text { 1992: Republic Act No. 7322, } \\
\text { Amendment to Republic Act No. 1161, } \\
\text { Section 1 } \\
\text { 1997: Republic Act No. 8282, } \\
\text { Amendment to Republic Act No. 1161, } \\
\text { Section } 1\end{array}$ \\
\hline 24 & $\begin{array}{l}\text { Republic of } \\
\text { Korea }\end{array}$ & High-income & 90 & $\begin{array}{l}\text { 1953: Labour Standards Act, Article } 74 \\
\text { 1987: Act on the Equal Employment for } \\
\text { Both Sexes } \\
\text { 2001: Amendment to Labour Standards } \\
\text { Act } \\
\text { 2007: Act on Equal Employment and } \\
\text { Support for Work-Family Reconciliation }\end{array}$ \\
\hline
\end{tabular}


Table A.1. (continued)

\begin{tabular}{|c|c|c|c|c|}
\hline & Country & Income group & $\begin{array}{l}\text { Length } \\
\text { of paid } \\
\text { maternity } \\
\text { leave } \\
\text { (days) }\end{array}$ & $\begin{array}{c}\text { Legislative provisions for duration } \\
\text { of maternity leave and year of its } \\
\text { enactment/amendment }\end{array}$ \\
\hline 25 & $\begin{array}{l}\text { Russian } \\
\text { Federation }\end{array}$ & $\begin{array}{l}\text { Upper-middle } \\
\text { income }\end{array}$ & 140 & $\begin{array}{l}\text { 1989: (i) Labour Code of the Russian } \\
\text { Soviet Federative Socialist Republic, } \\
\text { Article 165, (ii) Amendment to Labour } \\
\text { Code of the RSFSR, Article } 4 \\
\text { 1991: Resolution of the Supreme } \\
\text { Soviet of the USSR No. 1420-1, Urgent } \\
\text { Measures for the Improvement of } \\
\text { the Status of Women, the Protection } \\
\text { of Mothers and Children, and the } \\
\text { Strengthening of the Family, Article } 6 \\
\text { 1992: Law No. 2660-1, Additional } \\
\text { Measures for the Protection of } \\
\text { Maternity and Childhood, Article } 1 \\
\text { 1993: Law No. 3543-1, Amendment to } \\
\text { Labour Code of the RSFSR, Article } 101 \\
\text { 1997: Law No. 131-FZ, Amendment to } \\
\text { Labour Code of the RSFSR, Article } 1 \\
\text { 2002: Law No. 197-FZ, Labour Code of } \\
\text { the Russian Federation, Article } 255\end{array}$ \\
\hline 26 & Singapore & High-income & 112 & $\begin{array}{l}\text { 1989: (i) Act No. 17, Employment } \\
\text { Act, Section 95(1), (ii) Bill No. 20, } \\
\text { Amendment to Employment Act, } \\
\text { Section 19, (iii) Bill No. 22, Amendment } \\
\text { to Employment Act, Section } 24 \\
\text { 1996: Employment Act (Revised Edition } \\
\text { 1996), Article 76(1)(a) } \\
\text { 2005: (i) Act No. 41, Amendment to } \\
\text { Employment Act, Section 7, (ii) Act No. } \\
\text { 13, Children Development Co-Savings } \\
\text { Act, Section 9(1)(a), (iii) Act No. 42, } \\
\text { Amendment to Children Development } \\
\text { Co-Savings Act, Section } 4 \\
\text { 2009: Act No. 28, Amendment to } \\
\text { Children Development Co-Savings Act, } \\
\text { Section } 5\end{array}$ \\
\hline 27 & $\begin{array}{l}\text { Solomon } \\
\text { Islands }\end{array}$ & $\begin{array}{l}\text { Lower-middle } \\
\text { income }\end{array}$ & 84 & $\begin{array}{l}\text { 1996: Labour Act and Rules, Article } \\
\text { 42(1) }\end{array}$ \\
\hline 28 & Sri Lanka & $\begin{array}{l}\text { Lower-middle } \\
\text { income }\end{array}$ & 84 & $\begin{array}{l}\text { 1940: Maternity Benefits Ordinance } \\
\text { (No. } 32 \text { of 1939) (Cap. 140) } \\
\text { 1985: Maternity Benefits (Amendment) } \\
\text { Act, No. } 43 \\
\text { 2018: Maternity Benefits (Amendment) } \\
\text { Act, No. } 15\end{array}$ \\
\hline
\end{tabular}


Table A.1. (continued)

\begin{tabular}{|c|c|c|c|c|}
\hline & Country & Income group & $\begin{array}{l}\text { Length } \\
\text { of paid } \\
\text { maternity } \\
\text { leave } \\
\text { (days) }\end{array}$ & $\begin{array}{l}\text { Legislative provisions for duration } \\
\text { of maternity leave and year of its } \\
\text { enactment/amendment }\end{array}$ \\
\hline 29 & Tajikistan & $\begin{array}{l}\text { Lower-middle } \\
\text { income }\end{array}$ & 140 & $\begin{array}{l}\text { 1997: Labour Code, Article } 164 \text { 2015: } \\
\text { Law No. } 72 \text { of } 2 \text { December } 2002 \text { "On } \\
\text { Reproductive Health and Reproductive } \\
\text { Rights", as amended to } 18 \text { March } 2015\end{array}$ \\
\hline 30 & Thailand & $\begin{array}{l}\text { Upper-middle } \\
\text { income }\end{array}$ & 90 & $\begin{array}{l}\text { 1989: Announcement of the Ministry of } \\
\text { Interior Respecting Labour Protection } \\
\text { (B.E. 2515), Section } 18 \\
\text { 1993: Notification No. 13, Notification } \\
\text { of the Ministry of Interior on Labour } \\
\text { Protection } \\
\text { 1999: Labour Protection Act (B.E. } \\
\text { 2541), Section } 41\end{array}$ \\
\hline 31 & Turkey & $\begin{array}{l}\text { Upper-middle } \\
\text { income }\end{array}$ & 112 & 2003: Labour Act, Article 74 \\
\hline 32 & Uzbekistan & $\begin{array}{l}\text { Lower-middle } \\
\text { income }\end{array}$ & 126 & 1995: Labour Code, Article 233 \\
\hline 33 & Vanuatu & $\begin{array}{l}\text { Lower-middle } \\
\text { income }\end{array}$ & 84 & $\begin{array}{l}\text { 1983: Employment Act (as amended up } \\
\text { to 2010), Article } 36(1)\end{array}$ \\
\hline 34 & Viet Nam & $\begin{array}{l}\text { Lower-middle } \\
\text { income }\end{array}$ & 180 & $\begin{array}{l}\text { 1994: Labour Code, Article } 114 \\
\text { 2006: Law on Social Insurance, Article } \\
31 \text { 2013: Labour Code, amendment }\end{array}$ \\
\hline
\end{tabular}

Source: Women, Business and the Law 2018 database of the World Bank. Available at http://wbl.worldbank.org/; ILO's NATLEX database of ILO. Available at www.ilo.org/dyn/natlex/natlex4.home; and Working Conditions Laws database of ILO. Available at www.ilo.org/dyn/travail/travmain.home.

Note: For Australia and New Zealand, the duration of parental leave has been indicated as this provides paid leave that women may take at and around childbirth. 


\section{Annex II}

Table A.2. Effective coverage for mothers with newborns receiving maternity benefits in countries of Asia and the Pacific (with available data), 2015 or latest available year

\begin{tabular}{llc}
\hline \multicolumn{1}{c}{ Country } & $\begin{array}{c}\text { Mothers with newborns } \\
\text { receiving cash benefits, 2015 } \\
\text { or latest available year (\%) }\end{array}$ \\
\hline 1 & Armenia & 61.0 \\
2 & Azerbaijan & 14.0 \\
3 & Bangladesh & 20.9 \\
4 & China & 15.1 \\
5 & India & 41.0 \\
6 & Kazakhstan & 44.6 \\
7 & Kyrgyzstan & 23.8 \\
8 & Mongolia & 100.0 \\
9 & Myanmar & 0.7 \\
10 & New Zealand & 100.0 \\
11 & Philippines & 9.0 \\
12 & Russian Federation & 69.0 \\
13 & Tajikistan & 59.5 \\
14 & Viet Nam & 44.5 \\
\hline
\end{tabular}

Source: ILO, World Social Protection Database, based on the Social Security Inquiry; ILOSTAT; national sources. Cited in ILO (2017).

Note: $\quad$ Ratio of women receiving maternity benefits to women giving birth in the same year (estimated based on age-specific fertility rates published in the United Nations World Population Prospects: 2015 revision, or on the number of live births corrected by the share of twin and triplet births). 


\section{Annex III \\ Table A.3. Robustness check with a dummy variable ( 1 if a country has a paid maternity leave policy, 0 if none)}

3a: Infant mortality

\begin{tabular}{lcccc}
\hline & $\begin{array}{c}\text { All } \\
(\mathbf{1})\end{array}$ & $\begin{array}{c}\text { LMCs } \\
(\mathbf{2})\end{array}$ & $\begin{array}{c}\text { UMCs } \\
(\mathbf{3})\end{array}$ & $\begin{array}{c}\text { HICs } \\
(\mathbf{4})\end{array}$ \\
\hline Dummy variable & -0.836 & $-2.177^{\star}$ & 0 & -0.177 \\
& $(0.735)$ & $(1.013)$ & $()$. & $(0.195)$ \\
Immunization & $-0.222^{\star \star \star}$ & $-0.210^{\star \star \star}$ & $-0.200^{\star \star \star}$ & 0.00481 \\
Health expenditures & $(0.0309)$ & $(0.0356)$ & $(0.0504)$ & $(0.0177)$ \\
& $0.723^{\star \star \star}$ & $0.709^{\star}$ & $-1.188^{\star \star \star}$ & $-0.500^{\star \star \star}$ \\
Schooling & $(0.214)$ & $(0.275)$ & $(0.313)$ & $(0.0864)$ \\
& $14.96^{\star \star \star}$ & $13.17^{\star \star \star}$ & $23.29^{\star \star \star}$ & $-1.055^{\star}$ \\
Log GDP & $(1.349)$ & $(1.691)$ & $(3.012)$ & $(0.442)$ \\
& $-12.92^{\star \star \star}$ & $-7.392^{\star \star \star}$ & $-16.07^{\star \star \star}$ & $-1.511^{\star \star \star}$ \\
Year & $(1.205)$ & $(2.101)$ & $(1.128)$ & $(0.304)$ \\
$N$ & $\mathrm{FE}$ & $\mathrm{FE}$ & $\mathrm{FE}$ & $\mathrm{FE}$ \\
$\mathrm{R}^{2}$ overall & 542 & 318 & 128 & 96 \\
$\mathrm{R}^{2}$ within & 0.380 & 0.241 & 0.103 & 0.0272 \\
$\mathrm{R}^{2}$ between & 0.782 & 0.839 & 0.926 & 0.764 \\
\hline
\end{tabular}

Note: Standard errors are in parentheses.

Significance levels are: ${ }^{\star} 0.05,{ }^{\star *} 0.01,{ }^{\star * *} 0.001$.

All, full sample; LMCs, low- and lower-middle income countries; UMCs, upper-middle income countries; HICs, high-income countries; FE, fixed effects. 


\section{3b: Under-five mortality}

\begin{tabular}{|c|c|c|c|c|}
\hline & $\begin{array}{l}\text { All } \\
\text { (1) }\end{array}$ & $\begin{array}{l}\text { LMCs } \\
\text { (2) }\end{array}$ & $\begin{array}{l}\text { UMCs } \\
\text { (3) }\end{array}$ & $\begin{array}{c}\text { HICs } \\
\text { (4) }\end{array}$ \\
\hline \multirow[t]{2}{*}{ Dummy variable } & $-2.287^{\star}$ & $-3.756^{\star}$ & 0 & $-0.662^{\star *}$ \\
\hline & (1.024) & $(1.449)$ & (.) & $(0.203)$ \\
\hline \multirow[t]{2}{*}{ Schooling } & $23.47^{\star \star \star}$ & $21.20^{\star \star *}$ & $28.18^{\star \star \star}$ & -0.410 \\
\hline & (1.878) & $(2.418)$ & (3.315) & $(0.460)$ \\
\hline \multirow[t]{2}{*}{ Immunization } & $-0.323^{\star \star *}$ & $-0.318^{* * *}$ & $-0.169^{\star \star}$ & -0.0110 \\
\hline & $(0.0430)$ & $(0.0509)$ & $(0.0554)$ & $(0.0185)$ \\
\hline \multirow[t]{2}{*}{ Health expenditures } & $1.111^{\star \star *}$ & $1.027^{\star \star}$ & $-1.326^{\star \star \star}$ & $-0.276^{\star \star}$ \\
\hline & $(0.299)$ & $(0.394)$ & $(0.345)$ & $(0.0901)$ \\
\hline \multirow[t]{2}{*}{ Log GDP } & $-16.74^{\star \star \star}$ & $-13.92^{\star \star \star}$ & $-19.31^{\star \star \star}$ & -0.413 \\
\hline & (1.678) & (3.005) & $(1.241)$ & $(0.316)$ \\
\hline Year & FE & FE & FE & FE \\
\hline$N$ & 542 & 318 & 128 & 96 \\
\hline $\mathrm{R}^{2}$ overall & 0.423 & 0.260 & 0.0814 & 0.0328 \\
\hline $\mathrm{R}^{2}$ within & 0.780 & 0.837 & 0.936 & 0.838 \\
\hline $\mathrm{R}^{2}$ between & 0.542 & 0.438 & 0.0608 & 0.00377 \\
\hline
\end{tabular}

Note: Standard errors are in parentheses.

Significance levels are: ${ }^{\star} 0.05,{ }^{* \star} 0.01,{ }^{\star \star *} 0.001$

All, full sample; LMCs, low- and lower-middle income countries; UMCs, upper-middle income countries; HICs, high-income countries; FE, fixed effects. 


\section{REFERENCES}

Addati, L., N. Cassirer, and K. Gilchrist (2014). Maternity and Paternity at Work: Law and Practice Across the World. Geneva: ILO.

Aslim, E. G., I. B. Panovska, and M. A. Tas (2019). Does maternity leave duration affect labour force participation and productivity? Working Paper, SSRN Electronic Journal. Available at http://papers.ssrn.com/sol3/papers.cfm?abstract_id=3136631.

Chatterji, P., and S. Markowitz (2012). Family leave after childbirth and the mental health of new mothers. Journal of Mental Health Policy and Economics, vol. 15, No. 2, pp. 61-76.

Dagher, R. K., P. M. McGovern, and B. E. Dowd (2014). Maternity leave duration and postpartum mental and physical health: implications for leave policies. Journal of Health Politics, Policy and Law, vol. 39. No. 2, pp. 369-416.

Fallon, K. M., A. Mazar, and L. Swiss (2017). The development benefits of maternity leave. World Development, vol. 96, Issue C, pp. 102-118.

Grimshaw, D., and J. Rubery (2015). The Motherhood Pay Gap: A Review of the Issues, Theory and International Evidence. Conditions of Work and Employment Series, No. 57. Geneva: ILO.

International Labour Organization (ILO) (2014). Maternity and Paternity at Work: Law and Practice Across the World. Geneva.

(2016a). Assessment of the social security legislation for the ratification of the Social Security (Minimum Standards) Convention, 1952 (No. 102). International Labour Office, Social Protection Department. Geneva.

(2016b). Mongolia: A one-stop shop for accessible, transparent and efficient public service delivery. The Building Social Protection Brief. Geneva.

(2017). World Social Protection Report 2017-19: Universal Social Protection to Achieve the Sustainable Development Goals. Geneva.

Keck, W., and C. Saraceno (2013). The impact of different social-policy frameworks on social inequalities among women in the European Union: the labour-market participation of mothers. Social Politics: International Studies in Gender, State and Society, vol. 20, No. 3, pp. 297-328.

McCormick, L. K., and others (1997). Parental perceptions of barriers to childhood immunization: results of focus groups conducted in an urban population. Health Education Research, vol. 12, No. 3, pp. 355-362.

Nandi, A., and others (2016). Increased duration of paid maternity leave lowers infant mortality in low- and middle-income countries: a quasi-experimental study. PLoS Medicine, vol. 13 , No. 3.

Nikore, M. (2017). Supporting motherhood - or discouraging parenthood? A curious case of the extended maternity leave in India. South Asia@LSE blog. Available from http://blogs. Ise.ac.uk/southasia/2017/03/17/supporting-motherhood-or-discouraging-parenthooda-curious-case-of-the-extended-maternity-leave-in-india/.

Organization for Cooperation and Development (OECD) (2015). SIGI Regional Report: Europe and Central Asia. Paris. 
Pal, K., and others (2005). Can low income countries afford basic social protection? First results of a modelling exercise. Issues in Social Protection Discussion Paper, 13. Geneva: ILO.

Patnaik, A. (2019). Reserving time for daddy: the consequences of fathers' quotas. Journal of Labour Economics, vol. 37, No. 4, pp.1-54.

Stenberg, K., and others (2014). Advancing social and economic development by investing in women's and children's health: a new Global Investment Framework. The Lancet, vol. 383, No. 9925, pp. 1333-1354.

Waldfogel, J., Y. Higuchi, and M. Abe (1999). Family leave policies and women's retention after childbirth: evidence from the United States, Britain, and Japan. Journal of Population Economics, vol. 12, pp. 523-545.

Yilmaz, G., and others (2002). Factors influencing breastfeeding for working mothers. Turkish Journal of Paediatrics, vol. 44, No. 1, pp. 30-34. 